\title{
CAUSES OF TRACTOR BREAKDOWNS AND REQUISITE SOLUTIONS \\ A CASE STUDY OF SMALL TRACTOR USE IN RIAU PROVINCE, INDONESIA
}

\author{
Ujang Paman* \\ The United Graduate School of Agricultural Science Kagoshima University, \\ 1-12-24 Korimoto, Kagoshima 890-0065, Japan \\ Department of Agricultural Economics, Faculty of Agriculture, \\ Riau Islamic University, Jl. Kaharuddin Nst No. 113 P. Marpoyan, \\ Pekanbaru 28284, Riau, Indonesia, \\ S. Uchida, S. Inaba, and T. Kojima \\ Department of Agricultural Sciences, Faculty of Agriculture, \\ Saga University, 1 Honjou-machi, Saga City, Japan
}

Received 24 April 2006

\begin{abstract}
A survey has been undertaken to look into the causes of tractor breakdowns on field operations and the main constraints associated with repair and maintenance, and to recommend a solution to the problems in Riau Province. The owners of sixty-two small tractors were interviewed, from three regencies chosen of the Province in 2003. As a result, the working capacity of the tractors was relatively high and the average annual use was relatively low compared to the national average. Most tractor operators did not have sufficient skill to operate tractors. The tractor breakdowns resulted from operators' mistakes, fuel and oil defilement, rough field conditions, poor maintenance, intense use, and factory design. Inadequate repair shops, a lack of spare parts, and a shortage of mechanics in the local vicinity were the main factors curbing tractor repair. It was also found that inadequate finances led many farmers to ignore tractor maintenance. These suggest that tractor operators should be well trained and tractor-supporting facilities should be provided in rural areas. A mechanical extension officer and credit options should be made available for farmers.
\end{abstract}

Keywords: Tractor breakdowns, small tractor, repair practices, and repair costs

\section{INTRODUCTION}

During the last two decades, the Indonesian government through the ministry of agriculture has gradually introduced a farm mechanization scheme to farmers in order to modernize agriculture and increase production. In Riau, the provincial government, through the Agricultural Food

\footnotetext{
*Corresponding author e-mail: u_paman@yahoo.com
} 
Service, took an active role in demonstrating the advantages of mechanized farming mainly through using small tractors for rice cultivation. The effort has made much progress in increasing a number of tractors, especially small tractor in the province at the last five years. Of the 103,445 units of the national's total tractors in 2003, $650(6 \%)$ are in Riau Province [1]. The number of the tractors has increased more than double from 242 in 1998 [2].

In practise, most farmers face a number of problems in using the tractors. Breakdowns which are field stoppage due to sudden failure of a part [3] are major problems found in the Riau Province. During the last ten years, at least $10 \%$ of the total existing tractors remain idle every year, and approximately $6 \%$ of them fall into the serious breakdown category. In regard to the problems, a number of studies reported the effects of tractor breakdowns on the crop production process. The tractor breakdowns have wasted potential working time in the main season, as much as $26 \%$ and $15 \%$ in Thailand and Malaysia, respectively [4] and the problems were one of the causes of low annual use of tractors in Western Nigeria [5].

From an economic point of view, idleness due to machinery breakdowns can be very costly as a result of lost working time [6]. Repairs of broken down machines are also expensive [7], because the breakdowns consume resources; manpower, spare parts, and even lose of production [8]. Consequently, the repair costs become an important component of the total machine ownership costs [9]. It was found that about 53\% of total machine expenses in developing countries were for repairs of machine breakdowns [10].

Specifically, the causes of breakdowns can be different from one country to another due to differences in maintenance regimes, operator skills, infrastructure and working conditions, and other factors. Jacobs et al. [6] stated that machines may break down due to a design defect, physical damage, or normal wear and tear, but many times machines fail because of neglect and the lack of properly scheduled maintenance. It was reported that the high frequency of breakdowns may be attributed to the high cost of imported spare parts, misuse of tractors, and a failure of operators to carry out routine maintenance [11]. While a lack of spare parts and poor tractor maintenance were found to be the major causes of tractor breakdowns in Nigeria [12], these problems subsequently caused around $50 \%$ of tractors in the country to become unserviceable [13].

Ideally, successful mechanization, particularly the use of tractors, requires a number of supporting facilities for the satisfactory operations that, in many cases, have seldom been met mainly in developing countries. This study attempts to uncover specific issues associated to the breakdowns problems by investigating the causes of the tractor breakdowns in field operations and the main constraints confronting individual farmers in making repair and maintenance service, and to recommend solutions to the problems.

\section{MATERIALS AND METHODS}

Data for the study was collected by field surveys from October to December 2003 in three regencies in Riau Province, including Kuantan Sengingi, Rokan Hulu, and Siak (Fig. 1). The locations were selected specifically to represent the main tractor operational conditions faced in Riau Province. Sixty-two tractors and their owners were selected randomly for sample and they were interviewed by means of field visits to their houses or to their places of work. The number of the sample represented approximately $29 \%$ of the entire population of tractors in the selected regencies.

Each farmer interviewed was asked to provide information on their tractor make and type, purchase year, hectares of work, number and causes of breakdowns, number and kind of replacement parts, place and repairer of tractor breakdowns, length of repair, and detailed repair and maintenance expenses (parts, labour, maintenance, and transportation). In addition to this 
data, a number of problems facing individual farmers in making repairs, carrying out maintenance, and obtaining spare parts were also collected.

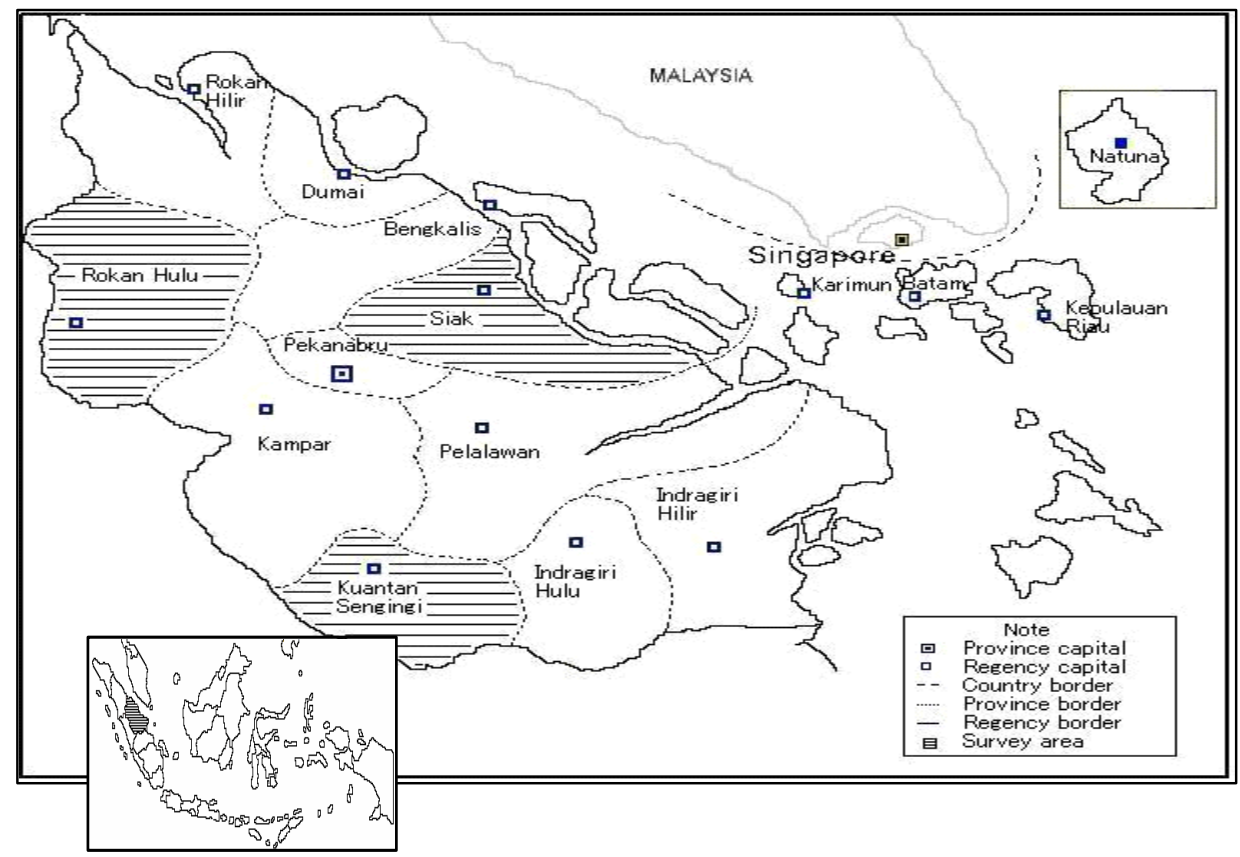

Fig. 1: Map of survey area.

\section{RESULTS AND DISCUSSIONS}

Of the 62 tractors surveyed, 55\% were manufactured by Yanmar, 29\% by Kubota, and the rest by other manufactures. The tractors averaged 4.7 years of age with a ranging from 1 to 12 years old. The engine power ranged from $7.5(5.6 \mathrm{~kW})$ to $10.5 \mathrm{hp}(7.8 \mathrm{~kW})$, with $8.5 \mathrm{hp}(6.3 \mathrm{~kW})$ being the most common type. The tractors were equipped with pairs of iron wheels, single mouldboard ploughs, puddlers, and wetland circle puddler. The iron wheel was used to prevent tractors becoming stuck in deep mud. The moldboard plough is commonly used for primarily tillage (ploughing) and the other implements are for secondary tillage (puddling) (Fig. 2).

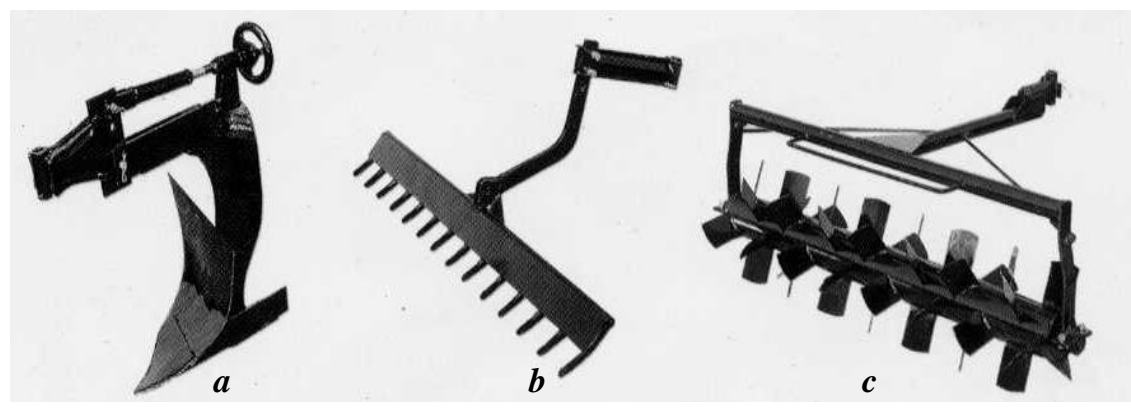

Fig. 2: Domestically designed implements for small tractor. a) Single moldboard plow, b) Puddler, c) wetland circle puddler. 
All of the tractors and implements were produced by domestic manufacturers located in Java and distributed by their dealers to Pekanbaru (capital of Riau Province). The tractors were purchased from the dealers, who offered farmers purchase discounts rather than guarantees.

\subsection{Tractor operator}

Double operators were highly common and the operators consisted of owners, relatives, or hired hands. The age of the operators ranged from 17 to 53 years with the average being 35 years. Approximately $50 \%$ of operators had graduated from elementary school, and $30 \%$ and $14 \%$ from secondary and high schools, respectively. The remaining $6 \%$ had no formal education. The operator's experience varied from 1 to 23 years with the average being 5 years. Most operators learned to operate tractors from their fathers, other farmers, or were self-taught and only $10 \%$ of them took part in short government-sponsored training programs. Discussions with operators revealed that there was a strong desire among them to participate in training. However, it was not easy for farmers to allow farmhands attend the training because the number of participants was extremely limited. Meanwhile, no training existed for tractor operators arranged by dealers or private institutions.

\subsection{Tractor working performance}

Tractor work concentrated on land preparation for growing rice. In survey areas, the rice is grown in widely diverse production environments, including wetland (irrigated lowland) and dryland (rain-fed lowland and upland). The tractors that worked in irrigated areas (including tidal-affected land) were mostly used twice a year under double cropping systems, while those used only once in rain-fed paddy field areas under single cropping system. Based on these conditions, the average work of tractors was 52 days seasonally ranging from 20 to 56 days. There was quite a variation among tractors due to local climate conditions.

Table 1: Field measurement of tractor working performance.

\begin{tabular}{cll|l|l}
\hline Items & Range & Average & CV*(\%) & National range** \\
\hline Working hours (h/day) & $5-9$ & 7.5 & 13 & 8 \\
Working capacity (h/ha) & $16-31$ & 22.5 & 22 & $14-17$ \\
$\quad$ Ploughing & $6-14$ & 9.7 & 25 & \\
$\quad$ Puddling & $8-17$ & 12.8 & 25 & $40-60$ \\
Annual use in hectare & $5-40$ & 21.4 & 47 & \\
Own farm & $0.25-4$ & 1.2 & 78 & \\
Hired service & $4.5-37$ & 19.9 & 49 & \\
$\quad$ Wet Season & $3-25$ & 14.2 & 39 & \\
$\quad$ Dry Season & $0-20$ & 7.2 & 101 & \\
Annual use in hours & $140-960$ & 458 & 46 & \\
\hline
\end{tabular}

Note: $*$ Coefficient of variation. Source: $* *=$ Central Bureau of Statistics, 2003.

From Table 1, it is found that working hours of tractors were $7.5 \mathrm{~h} /$ day on average. There were a little variation between tractors as shown by coefficient of variation due mainly to different 
number of operators and local custom of the working hours. The working capacity was also found to slightly vary among tractors with an average of $22.5 \mathrm{~h} / \mathrm{ha}$ for both operations. The required time was longer than the national average and similar operations in West Java at 14.5 $\mathrm{h} / \mathrm{ha}$ [14] for a tractor of the same size. Field plot sizes and tractor operator skills were possible main causes for the differences. The working capacity was found to differ between ploughig and puddling operations. The puddling operation required more time than the ploughing operation because this step needed to be repeated several times to complete the work. The relative length of working capacity for both operations also depended on supplying water into the field.

Most farmers did "custom hire" for neighbouring farmers in addition to work on their own farms. Some farmers only operated in a limited radius because of inadequate access to users' fields which held down a number of contract works. It was found that the annual use also varied among tractors with the average being $21.44 \mathrm{ha}$ and this is equivalent to $458 \mathrm{~h}$ (Table 1). About $95 \%$ of the total annual work was from the custom service and the remaining $5 \%$ was from the farm alone. The annual use was found to differ between rice cropping seasons. Approximately $66 \%$ of the total annual use was done during the wet season and $34 \%$ during the dry season. The wet season, in which the total paddy field areas are usually planted with rice, is the most important season for growing rice [15].

The results are clear that the amount of annual use depends mainly on the number of contract work from hiring farmers and rice cropping patterns. Discussions with farmers revealed that other factors, such as frequency of tractor breakdowns and repair times, shape and size of field plots, operator skill and experience, and the local climate conditions also affected the tractor annual use. For example, by using skilled and experienced operators, the annual use is expected to increase as a result of increasing the speed of tractors and decreasing the frequency of tractor breakdowns.

Although it is not common in the survey areas, about $11 \%$ of the tractors were used at least once for transportation activities in short distances. By attaching a trailer to the rear, the tractors were employed to carry farm products, firewood, and shopping goods from local market centres during off-seasons. These uses concerned the farmers' household works themselves and required times from 8 to $65 \mathrm{~h} / \mathrm{yr}$.

\subsection{Tractor breakdowns and repair practices}

According to the survey, about $95 \%$ of the tractors experienced at least one field operation stoppage in a year due to breakdown problems. It is observed that one or more parts were found to be broken when a breakdown occurred. Most of the breakdowns occurred during puddling $(68 \%)$ followed by ploughing operation and transportation use as $26 \%$ and $4 \%$, respectively. The remaining $2 \%$ occurred during travelling to and from the field due to poor farm roads. The most frequent breakdowns occurred for puddling operation due to the operation required heavily stressed tillage work under wet conditions.

The number of broken parts, frequency, and causes of the breakdowns are presented in Table 2 . According to the table, about $21.6 \%$ of the breakdowns resulted from broken belts followed by injection nozzle $(15.2 \%)$, puddlers $(12 \%)$, plunger and piston ring $(9.6 \%)$. They contributed $68 \%$ of the total breakdowns and the remaining $32 \%$ were caused by pistons, wheel bearings, wheel bolt/nuts, connecting rods, oil seals, metal, and mouldboard.

With regard to the causes of the breakdowns, field conditions were main causes of the broken mouldboard, puddlers, wheel bearing and belts. Discussions with farmers suggest that the heavy weeds growing on field surfaces; and poor land cleaning that had left tree stumps in the field ground were major causes of the excessive wear of implements. Smearing with mud water primarily during puddling operation caused the belts to break faster. Most farmers stated that most belts got broken after operating two or three seasons on wet conditions. Furthermore, 
wheel bearings and wheel bolts/nuts suffered excessive wear due to operation under similar conditions.

Table 2: Broken parts, frequency and causes of the breakdowns.

\begin{tabular}{lccccccc}
\hline & & & \multicolumn{5}{c}{ Causes of breakdowns (\%) } \\
\cline { 5 - 8 } Broken parts & $\begin{array}{c}\text { Number } \\
\text { of cases }\end{array}$ & $\begin{array}{c}\text { Frequency } \\
(\%)\end{array}$ & $\begin{array}{c}\text { Operator } \\
\text { fault* }\end{array}$ & $\begin{array}{c}\text { Fuel } \\
\text { and } \\
\text { oil }\end{array}$ & $\begin{array}{c}\text { Field } \\
\text { conditions }\end{array}$ & $\begin{array}{c}\text { Poor } \\
\text { maintenance }\end{array}$ & $\begin{array}{c}\text { Other } \\
\text { factors }\end{array}$ \\
\hline Belts & & & & & & & \\
Injection & 27 & 21.6 & 14.8 & - & 37.0 & 29.6 & 18.5 \\
nozzle & 19 & 15.2 & - & 52.6 & - & - & 47.4 \\
Puddlers & 15 & 12.0 & - & - & 66.7 & - & 33.3 \\
Plunger & 12 & 9.6 & - & 33.3 & - & - & 66.7 \\
Piston ring & 12 & 9.6 & 16.7 & 25.0 & - & 58.3 & - \\
Piston & 9 & 7.2 & 11.1 & 33,3 & - & 55.6 & - \\
Wheel bearing & 9 & 7.2 & 22.2 & - & 44.4 & 22.2 & 11.1 \\
Wheel bolt/nut & 6 & 4.8 & - & - & 50.0 & 33.3 & 16.7 \\
Connecting & 5 & 4.0 & 20.0 & - & - & - & 80.0 \\
rod & 4 & 3.2 & - & - & 25.0 & 25.0 & 50.0 \\
Oil seal & 4 & 3.2 & 25 & - & - & 50.0 & 25.0 \\
Metal & 3 & 2.4 & - & - & 100.0 & - & - \\
Mouldboard & & & & & & & \\
\hline
\end{tabular}

Note: Operator's fault included improper or careless handling of tractor and accidents Other factors consisted of overload, factory design, and normal wear

Poor maintenance caused mostly piston ring, piston and metal got broken. Interviews with farmers revealed that failure to change oil at the correct times had caused the engine troubles. It was found that about $47 \%$ of farmers scheduled more than the recommended interval of 100 hours. Meanwhile, most injection nozzles suffered damages due to fuel and oil. These also caused plunger, piston, and piston ring defects. Presumably, dirt and dust in both the fuel and oil would have caused excessive wear of the components. Jacobs et al. [6] claimed that dirty oil, a lack of oil, or foreign objects can cause the scratches and scores on the pistons. Few farmers said that the use of inferior fuel and oil, resulting from adulteration had also caused frequent damages and major losses. It is because of the fuel and oil were commonly bought from unreliable local suppliers, while gas station that sell subsidized fuel and fine oil is not found around the village areas. Another consequently, the fuel price is always $20 \%$ higher than in the gas station.

Although it is not main causes, operators' fault contributed significantly to the tractor breakdowns. Improper or careless handling of the tractors and rough tractor handling were dominant factors in causing the breakdowns. In addition, besides normal wear, other factors causing premature failures were factory design, intense usage, and poor farm roads. According to the experience of some farmers, the pivot of the puddlers broke frequently due to being too small in design. The intense usage of the tractor during peak seasons also contributed to broken parts. It was found that tractors used more than 30 ha annually required engine overhaul after three or four years. The poor road on farm level caused few accidents during travelling to and from the field. 
Moreover, Table 3 shows that most of the parts needed to be replaced after suffering damage and only implements required any repairs. It is because the implements frequently had broken on teeth and the pivot of the puddlers and got fractures on the mouldboard blade. These could be repaired easily at any local welding workshop. Nevertheless, few farmers took them out of the area to acquire superior weld quality.

Table 3: Broken parts, service need and level, and repairer of tractors.

\begin{tabular}{lcccccc}
\hline Broken parts & $\begin{array}{c}\text { Numbe } \\
\text { r of } \\
\text { cases }\end{array}$ & $\begin{array}{c}\text { Service } \\
\text { need }\end{array}$ & $\begin{array}{c}\text { Service } \\
\text { level }(\%)\end{array}$ & \multicolumn{2}{c}{ Repairer of tractors (\%) } \\
\cline { 5 - 6 } & & & & $\begin{array}{c}\text { Farmers } \\
\text { (operators) } \\
\text { themselves }\end{array}$ & $\begin{array}{c}\text { Local } \\
\text { repair } \\
\text { shops }\end{array}$ & $\begin{array}{c}\text { Other } \\
\text { repair } \\
\text { shops }\end{array}$ \\
\hline Belts & 27 & Change & 81 & 100 & 0 & 0 \\
Injection nozzle & 19 & Change & 26 & 32 & 63 & 5 \\
Puddlers & 15 & Repair & - & 0 & 60 & 30 \\
Plunger & 12 & Change & 17 & 8 & 42 & 50 \\
Piston ring & 12 & Change & 42 & 0 & 16 & 84 \\
Piston & 9 & Change & 0 & 0 & 11 & 89 \\
Wheel bearing & 9 & Change & 33 & 0 & 78 & 22 \\
Wheel bolt/nut & 6 & Change & 83 & 100 & 0 & 0 \\
Connecting rod & 5 & Change & 0 & 0 & 20 & 80 \\
Seal & 4 & Change & 25 & 25 & 25 & 50 \\
Metal & 4 & Change & 0 & 25 & 25 & 50 \\
Mouldboard & 3 & Repair & - & 0 & 67 & 33 \\
\hline
\end{tabular}

Note: * Repair shops available in or around village area, ** Repair shops in the regency capital or dealer in province capital.

The results in Table 3 also indicate that there were insufficient shops to supply spare parts in the survey areas as shown by low service level. Consequently, many farmers were frustrated when their tractors broke down due to lack of spare parts in village areas. The higher service levels were found for wheel bolt/nut and belts to about $83 \%$ and $81 \%$, respectively. An $83 \%$ service level means that $17 \%$ of the parts demanded were not available. The higher service levels of these parts were, belts for example, contributed mostly by farmers stocks rather than by local suppliers. Similar cases were found only for injection nozzles, plungers, piston rings, wheel bearings and seals. On the other hand, the broken down tractors that resulted from piston, connection rod, and metal damages were subject to delay. Survey showed that a few broken tractors remained idle for a season due to difficulties in getting the spare parts. They had to be procured by order from local (repair) shops or purchased directly from dealers when the spare parts were locally unavailable. It caused procurement of spare parts frequently became costly and was, in some cases, even more expensive than the actual cost of repair.

Moreover, farmers or local repair shops had difficulties in accessing spare part suppliers located out of the village area, so it took longer to find or wait on spare part orders. It has since been discovered that the time required waiting on spare parts ranged from 4 - 30 days with an average of 16 days. It suggests that the farmers should keep a stock primarily of readily broken parts to prevent the delayed repair. Nevertheless, the best way to overcome the problems is to establish spare part depots in village areas. It could, for example, help farmers shorten the waiting time to even one day or further still, cut down on transportation costs. 
According to Table 3, there weren't any suitable workshops to carry-out tractor repairs in the survey area, particularly for the major repair category. Farmers performed minor repairs in a small number of the breakdown cases. There were only $15 \%$ of farmers who had the skills to make the repairs and they were trained and experienced operators. Local repair shops that were actually set up to repair local cars and trucks mostly did the minor repairs. The broken implements, for example, were welded by local blacksmiths.

In cases of serious breakdowns, such as engine overhauls, most tractors were sent to other repair shops out of the village area and needed 10 - 30 days to repair (Table 4). The repair, however, required a high level of skill and sophisticated tools; whereas the local repair shops had inadequate tools and a shortage of mechanics to do the repairs. Consequently, the repair included an extra cost to transport broken tractors long distances. These results stress the need for adequate repair shops and qualified mechanics in village areas. Discussions with farmers revealed that there was not a local investor interested in establishing a complete tractor repair shop because it would not be economical under the conditions of only a small number of tractors. In addition, farmers had very limited access to expert advice from dealers or to the machinery section of the province's agricultural food service. Also, the agricultural extension officers had no knowledge on how to advise farmers in overcoming tractor problems.

The time required for tractor repair is given in Table 4. Repairs which were done by either local repair shops or the farmers themselves required $2.8 \mathrm{~h}$ to make a minor repair and $10.9 \mathrm{~h}$ for a major repair on average. It is clear that the minor and major repairs could be done by local repair shops in a short time if spare parts were available locally.

Table 4: Actual time required for repairing tractor breakdowns.

\begin{tabular}{lllll}
\hline $\begin{array}{l}\text { Repair } \\
\text { categories }\end{array}$ & $\begin{array}{l}\text { Farmers or local repair shops } \\
\text { (hour) }\end{array}$ & $\begin{array}{l}\text { Repair shop out of the area } \\
\text { (day) }\end{array}$ & \\
\cline { 2 - 5 } & Time range & Average time & Time range & Average time \\
\cline { 2 - 5 } Minor repair & $1-5$ & 2.8 & - & - \\
Major repair & $5-21$ & 10.9 & $10-30$ & 17 \\
\hline
\end{tabular}

\subsection{Repair costs}

Table 5 highlights component costs resulting from repair process. The lack of spare parts and higher prices in the survey area caused a high cost of replacement parts. Of the Rp685 thousand average annual repair cost, approximately $71 \%$ was replacement parts. This is because most spare parts were bought outside the village area, namely from either shops in the regency capital or dealers. Farmers sometimes had to purchase spare parts which were more expensive in the local and regency capital shops than at the dealers. Survey showed the price differences ranged from $38 \%$ to $47 \%$ and $15 \%$ to $33 \%$ for local and regency capital shops, respectively. These different prices resulted primarily from long distances between farm areas and shops. In the village of Bunga Raya (surveyed in the Siak Regency) for example, the distance is $26 \mathrm{~km}$ to the regency capital and $120 \mathrm{~km}$ to the province capital, where complete spare parts can just be purchased. In addition, the spare parts are frequently susceptible to price fluctuations, which arise from the varying exchange rate of the Indonesian Rupiah to the US dollar. Also, the relatively high annual inflation causes spare parts to become increasingly more expensive.

The long distance to centrally located workshops and service facilities increased the difficulty in obtaining spare parts and the high costs of transport are passed on to the customers. It contributed $10 \%$ of the total repair costs and about $14 \%$ and $5 \%$ of the costs were labour and 
maintenance costs, respectively. The maintenance costs here included greasing for moving parts, cleaning, and protecting tractors during field operations. The low maintenance cost may reflect poor maintenance done by farmers in survey areas.

Surveys show that the lack of attention of some farmers toward maintenance and occasionally delay repairs also attributed to their economic status. Financial problems resulting from low farm incomes created difficulties for farmers wishing to pay workshop costs, purchasing replacement parts, and providing protectors for tractors. In a number of cases, replacement of broken parts was sometimes postponed due to insufficient funds. Farmers are accustomed to sell rice production after harvesting and spend all their money on temporary needs. Consequently, they often have a financial difficulty when the money is needed primarily for repairing and maintenance of tractors. It suggests that a system needs to be arranged for farmers to finance tractor repairs and replacement parts.

Table 5: Component costs for repairing tractors.

\begin{tabular}{llll}
\hline Component costs & Value range (Rp000) & Average (Rp000) & Percentage \\
\hline Replacement parts & $23.75-1,965.50$ & 550.05 & 71 \\
Labour charge & $2.50-530.00$ & 110.00 & 14 \\
Maintenance & $18.25-94.50$ & 37.47 & 5 \\
Transportation & $15.00-400.00$ & 75.19 & 10 \\
\hline Total & $20.00-2,871.00$ & 685498 & 100 \\
\hline
\end{tabular}

Note: Rp1000 is equivalent to about U.S.\$0.118 according with an average of exchange rate in 2003.

\section{CONCLUSIONS AND RECOMMENDATIONS}

The average working capacity was $22.5 \mathrm{~h} / \mathrm{ha}$ and the average annual usage was 21.44 ha (458 equivalent hours), of which 8 to $65 \mathrm{~h}$ was spent each year on transportation. Most tractor operators did not have sufficient skill operate tractors due to inadequate training programs. The tractor breakdowns on field operations could have resulted from operators' mistakes, fuel and oil adulterations, rough field conditions, poor maintenance, factory design, intense usage, and poor farm roads. Inadequate repair shops and a shortage of local mechanics caused the repair took longer and required high costs especially for replacement parts and transportation. Unavailability of complete spare depots and difficulty access to spare parts centre (dealers) caused low service level in the survey areas. Financial problems resulting from low farm incomes also contributed to lack of attention of some farmers toward maintenance and delay repairs.

The findings lead to the following recommendations:

1. Tractor hire service should be encouraged to increase tractor annual use.

2. Tractor operators should be better trained to make correct operations, prevent engine troubles and accidents, and perform good maintenance and service.

3. Farmers should always keep stock of spare parts, but the establishing of spare parts depot is best way to ensure regular supplies and low price of necessary parts.

4. Adequate service centres (workshops and mechanics) should be established in the village areas to ensure any repairs done in the local areas, so that time required to repair can be shorter and delayed repairs can be avoided. 
5. Government should provide training programs for all operators and mechanical extension officer to advice farmers in preventing tractor breakdowns.

6. A credit system should be made available for farmers to finance tractor repairs and replacement parts.

\section{REFERENCES}

1. Central Bureau of Statistics. (2003), Statistics of Indonesia

2. Statistical Office of Riau Province (1999), Statistics of Land and Agricultural Equipments Use, Pekanbaru.

3. Hunt, D. (1983), Farm power and machinery management. Eighth Addition, Ames, Iowa State University Press, pp. 66-69.

4. Chancellor, W.J. (1971), Mechanization of small farms in Thailand and Malaysia by tractor hire services, Transactions of the ASAE, 14(6), pp. 847-854, 859.

5. Kolawole, M.I. (1972), Economic aspects of tractor contracting operations in Western Nigeria. Journal Agricultural Engineering Research, 17, pp. 289-294.

6. Jacobs, C.O., Harrell, W.R., and Shinn, G.C. (1983), Agricultural power and machinery, McGraw-Hill, Inc. New York.

7. Hunt, D. (1971), Equipment reliability: Indiana and Illinois data. Transactions of the ASAE, 14(5), pp. 742-746.

8. Dodson, B. (1994), Determining the optimum schedule for preventive maintenance. Quality Engineering, 6(4), pp. 667-679.

9. Ward, S.M., McNulty, P.H., and Cunney, M.B. (1985), Repair costs of 2 and 4 WD tractors. Transactions of the ASAE, 28(4), pp. 1074-1076.

10. Inns, F.M. (1978), Operational aspect of tractor use in developing countries - A case for the small tractor, The Agriculture Engineer, Summer Issue: 52-54.

11. Adekoya, L.O., and Otono, P.A. (1990), Repair and maintenance costs of agricultural tractors in Nigeria. Tropical Agriculture, April Issue, 67(2), pp. 119-122.

12. Aneke, D.O. (1994), A Survey of farm power problem in Nigeria. Applied Engineering in Agriculture, 10(5), pp. 623-626.

13. Babatunde, O.O. (1996), An appraisal of the problem of wheeled tractors used in Nigerian Agriculture. Agricultural Mechanization in Asia, Africa and Latin America, 27(3), pp. 2326.

14. Singh, G. and Siswasumarto, H. (1988), Farm mechanization in West Java, Indonesia. Agricultural Mechanization in Asia, Africa and Latin America, 19(1), pp. 9-13.

15. Khan, M.M. (1996), A manual of food crops production in ISDP locations, Trans Intra Asia Co. in Association with Mott Mac Donald Limited, Indonesia. 